\title{
„AZ OKTATÁS ALAPVETŐ ÁLLAPOTA A STABILITÁS...
}

\section{Chrappán Magdolna}

\author{
a Debreceni Egyetem BTK Neveléstudományok Intézetének \\ föiskolai docense \\ chrappanm@gmail.com
}

...lassú változtatásokkal" (107. o.). Így szól az idézet, aminek az elejét címnek választottam Gordon Győri János legújabb, Tanórakutatás címü könyvét bemutatandó. A cím kissé félrevezető lehet, ahogyan minden kontextusából kiragadott gondolat az lehet. Fontos intelem azonban a szerző fenti megállapítása mindazoknak, akik hisznek csodamódszerek, csodareformok létezésében. A pedagógia gyakorlatát ismerök és müvelők körében remélhetően kevesen vannak ilyenek, de ha igen, nekik szól ez a könyv. Meg azoknak, akik azt gondolják, csak nagyon kitartó, aprólékos munkával juthatunk előre. És szól azoknak is, akik nem tudnak ezekben a kérdésekben döntetni vagy azért, mert még nincs tapasztalatuk, vagy azért, mert már nagyon is sok van. Gordon Györi János legújabb könyve egy olyan, eredetileg japán módszert mutat be, amelyért nagyon könnyü lelkesedni, magával ragadja az olvasót annak kézenfekvő logikája, látszólag könnyü megvalósíthatósága. Belegondolva persze abba, hogy milyen is lehet szó szerint követni egy mások által kidolgozott óratervet, milyen lehet nem improvizálni egy tanítási órán, és milyen lehet aztán (meg elötte is) a produktumot ízekre szedni, majd esetleg átdolgozás után újra megtartani ugyanazt az órát, befejezésül pedig mindezt zárótanulmány formájában nyilvánosságra hozni. Nos, az olvasói hevület ekkor kicsit alábbhagy. Azonban csak átmenetileg. A szerző tökéletes professzionalizmussal vezeti az olvasó gondolatait, nem elidegenítve a szokásainkkal, kultúránkkal szinte ellentétes pedagógusi szemlélettől. Csalogat bennünket tovább, és követjük, bízva abban, hogy érdemes. Nem is csalódunk. A könyv igazi pedagógiai élmény, többszöri olvasás után arra is rájövünk, miért.

A tárgyilagos elemzés a müről először azt jegyzi meg, hogy a Gondolat Kiadó és az ELTE PPK Neveléstudományi Intézete közös sorozatának, az Oktatásmódszertani Kiskönyvtárnak a kilencedik kötete. Magán hordozza mindazon jegyeket, amelyek a sorozat koncepciójából következnek: tanárok, oktatók, hallgatók számára gyakorlatközeli problémák, kérdések átfogó, lényegre törő bemutatása, amelyek így többnyire bonyolult transzferek nélkül alkalmazhatók az oktatási gyakorlatban. A Tanórakutatás kicsit el is tér azonban sorozatbeli társaitól: olyan témát mutat be, amelynek az elterjedtsége, de még az ismertsége is csekély, magyar viszonylatban mindenképp. Pusztán ebből következően is alapmü a kötet, a tanóraku- 
tatás módszerének első magyar nyelvü összefoglalása. Születtek már a témáról tanulmányok, többnyire szintén Gordon Györi János tollából, ám ez a könyv tulajdonképpen a szerző elmúlt években szerzett saját tapasztalatainak, kutatásainak szintézise.

Rögtön az első fejezet második bekezdésében megtaláljuk a definíciót: „A tanórakutatás a tanárok kollaborációján, kezdeményező együttmüködésén nyugvó, szorosan az iskolai, órai tevékenységhez kötődő pedagógiai és módszertani fejlesztő módszer." (9. o.) A kötet egészére jellemző ez a világos, egyértelmü megfogalmazás, a fogalmi biztonság és a szövegalkotás tisztasága. Ezzel a stílussal sokkal hatékonyabban érhető el az a cél, hogy minél szélesebb körben, minél közérthetőbben megismerjék a tanórakutatás módszerét és kultúráját.

Az első két fejezet rövid áttekintést ad a tanórakutatás történetéröl, és megvalósításáról. A mindössze 12 oldalnyi két fejezet legfontosabb funkciója egyrészt az, hogy beágyazza a tanórakutatást abba a társadalmi kontextusba, amelyben természetes, hogy a tanárok együttmüködnek, ahol időt, energiát nem sajnálva a tökéletességig igyekeznek minden apró mozzanatot csiszolni; másrészt két, áttekintő ábrával szemlélteti a tanórakutatás folyamatát. A szerző szerint, „A tanórakutatás tevékenységsorának lépéseit egy ciklikus folyamat lépéseiként lehet felfogni [...]: 1. egy tanári munkacsoport létrehozása, a pedagógiai célok kidolgozása; 2. egy konkrét tanítási óra eltervezése az adott pedagógiai cél jegyében (az ilyen órák neve: kutatási óra); 3. az óra megtartása, megfigyelése, megvitatása; 4. szükség esetén az óra újratervezése és ismételt megtartása; 5. a tanulságok összegzése és rögzítése, illetve szükség esetén egy újabb óra eltervezése és kivitelezése, s az így levonható tanulságok végső megbeszélése és rögzítése.” (17. o.) Hangsúlyozza, hogy - más módszerekhez hasonlóan ezt is csak javaslatnak kell tekinteni, hiszen „olyan megközelítésmódról van szó, amely nem kívánja önmagáról azt állítani, hogy feltétlenül és minden körülmények közepette hatékonyan müködik [...] de azt igen, hogy megfelelő körülmények megléte vagy kialakítása esetén az órakutatás módszere hatékonyan működhet.” (11. o.) A módszer alkalmazásának e felfogása végigvonul a további fejezeteken is, aminek az egyik legfőbb oka az, hogy a módszer a mi fogalmaink szerint rendkívül akkurátus, feszes lépések szerint müködik. „Az órakutatás egész processzusát érdemes úgy fölfogni, mint szakmai protokollt; vagyis érdemes minden flexibilitásával együtt is olyan, határozottan szabályozott tevékenységsort látni benne, amelyben az egyes elemeknek és az elemek egymáshoz kapcsolódásának sorrendi és egyéb vonatkozásokban is megvan a maguk értelme, jelentése, funkciói." (16. o.) Ezt már a harmadik fejezet elején olvashatjuk, amely a mü legnagyobb szerkezeti egysége. Ez szól a tulajdonképpeni tanórakutatásról. A harmadik fejezet a mü legerősebben strukturált része, öt alfejezetet, azokon belül pedig összesen negyvenhat (!) szövegszintet tartalmaz. Ez az aprólékos tagoltság kiválóan átláthatóvá, plasztikussá és barátságossá teszi a mondanivalót. A szövegtagolásnak ezen túl didaktikai feladata is van: ebben a fejezetben ismerjük 
meg a tematikus csomópontokat, a tanórakutatás legfontosabb paramétereit, amelyek a későbbi fejezetekben újra meg újra visszaköszönnek, más-más elemzési szempontok, kutatási, alkalmazási kontextusok szerint. Gordon Győri János ebben a fejezetben aprólékosan vezeti végig az olvasót a tanórakutatáson, kitérve még olyan marginálisnak tünő elemekre, mint hogy hová álljanak az órán részt vevő megfigyelők (Japánban minden látogató áll az órákon), vagy mikor érdemes a vendégeknek ételt-italt felszolgálni. Látszólag megmosolyogtató részletek ezek, de a rendezvényszervezésben járatos olvasók tudják, hogy ezek mennyire fontos elemei a mégoly erős szakmai tartalmú alkalmaknak is. Ehhez hasonló felbontású leírás szól a pedagógiai folyamatokról is, szinte receptszerúen. Miközben a tanórakutatás folyamatelemei sorban követik egymást, a szerzö folyamatosan értelmezi, magyarázza az egyes elemeket, összeveti a japán pedagógusszemléletet a mi viszonyainkkal. Ez a párhuzamos narráció segíti az olvasót a folyamat megértésében, sőt, interiorizációjában is.

A további fejezetekben az általánosítható pedagógiai tanulságokról, a különféle implementációs feltételrendszerekről, a sikeres alkalmazás esélyeiről szólnak. A negyedik fejezet az eredeti japán koncepció hongkongi/svéd és kínai változatát mutatja be. (Az előbbi egy magyar származású kutató, Ference Marton nevéhez füződő tanuláskutatási modellre épül.) Megismerhetjük a fenomenográfia fogalmát és a variációs elméletet, amelyek elgondolkodtatnak, $\mathrm{s}$ azt a kérdést is felvetik, hogy vajon miért nem evidensek a benne foglaltak minden gyakorló pedagógus számára? Eszerint ugyanis a tanítási-tanulási folyamat során két fontos kiindulási pont van: 1. a tanulók tanulásmódjának megértése, 2. megérteni, mi az a tanár felfogásmódjában, ami akadályozza az első pont megvalósulását és azt, hogy a tanítási helyzeteket megfelelően oldja meg. Marton szerint a fejlesztés csak konkrét tantárgyi-tanórai szituációkból kiindulva lehetséges, szemben az eredeti japán koncepcióval, amely megengedi, hogy a tanórakutatás során általánosabb pedagógiai problémákat is kutatási témává tegyenek (például, miképpen lehetne a gimnazisták magyartanításában a csoportmunkát hatékonyabban alkalmazni, vagy miképpen tudnánk elérni, hogy a diákjaink valóban élvezzék a kémiaórákat és tanuljanak is rajta [44.o.]). A kutatási tapasztalatok azt mutatják, hogy ez mindegyik tanulónak, de leginkább a gyengébben teljesítő diákoknak hasznos. E fejezetben fogalmazódik meg, hogy a döntéshozók csak a méréssel alátámasztott kutatási eredmémyeket tekintik tudományosnak, $\mathrm{s}$ kevésbé értékelik a pedagógusi tevékenységkutatásokat, és az ebből kinövő attitüd-, nézet-, metodikaikultúra-fejlesztéseket. Nem megnyugtató, hogy a mérésfetisizmus (ha mégoly érthető is bizonyos esetekben) nemcsak magyar sajátosság. Az ötödik fejezet - címében is jelzetten - a tanórakutatás céljaival és hasznával foglalkozik. Az első részben a szerző az általa alapmünek tekintett könyv (Stigler - Hiebert, 1999.) alapján szedi pontokba a tanórakutatás hatékonyságát megalapozó szakmai elveket és a sikeres müködés feltételrendszerét: a modell alapja a hosszú távú, folyamatos fejlesztés; az, hogy diákokra, a konkrét tanulási tevékenységre fókuszál; a 
pedagógiai munka direkt fejlesztése konkrét tanítási kontextusba ágyazva történik; kezdeményező tanári együttmüködésen alapszik; a módszer egyik legfontosabb haszna, hogy a szakmai kompetencia érzését biztosítja a részt vevő tanároknak. A fejezet második részében a tanórakutatás tanárképzésben és -továbbképzésben betöltött lehetséges szerepéről olvashatunk. Tökéletesen érezhető a több mint 30 oldalas szakaszban, ahogyan kiteljesedik és ötvöződik a szerző kutatói, tanárképzési és gyakorló középiskolai tanári tapasztalata, tudása. Kikristályosodott, rendkívül meggyőző erejü, és már mondanunk sem kell, precízen strukturált gondolatfolyamot olvashatunk.

A bevezetés és folyamatos müködtetés kérdéseivel foglalkozó hatodik fejezet a tanórakutatás korábban bemutatott, dúsan elágazó folyamatának esszenciáját tartalmazza, miközben két új elemet még ideemel a szerző. Az egyik a szervezetelméletből származó modell, a tanuló szervezet iskolákra vonatkozó rövid gondolata, ami a szervezeti tagok, esetünkben a pedagógusok állandó és elengedhetetlen együttmüködését hivatott alátámasztani. A második új elem az, hogy a tanórakutatáshoz megfelelően színvonalas curriculumra van szükség. Ez pedig nagyon fontos feltétel, amely mindenkit „kijózanít”, aki azt gondolná, hogy a tanórakutatás eddig megismert módszere minden tanítással kapcsolatos problémát megold. Ha jobban belegondolunk, nem is meglepő ez, hiszen a tanórakutatás deklaráltan, a szerző által is folyamatosan hangsúlyozottan metodikai problémamegoldó és fejlesztő módszer. Csak azt követően müködik, ha elkészültek a megfelelő minőségü tantervek.

Az utolsó, hetedik fejezet a hazai implementációs lehetőségek elemeit veszi sorra: intézmények, szakmai szervezetek, technikai eszközök, időbefektetés, tanári kollaboráció, kutatási óra, külső szakértők, komplex óravázlat, záró összegezés, valamint egy rövidke alfejezet szól a hazai példákról, amelyek sora biztosan gyarapodni fog a könyv megjelenését követően.

Gordon Györi János olyan mintaszerü pedagógiai müvet alkotott, amely nemcsak kutatási ízelítőt, szakirodalmi áttekintést (81 tételes bibliográfia) nyújt, hanem tökéletesen betölti a tanárképzési, -továbbképzési tankönyv funkcióját is, arányos szerkezeti tagolással, érthetö, világos nyelvezettel, tudatos redundanciával, amely mégis mindig előrelendíti az olvasó gondolatait, és észrevétlenül meg is tanítja a témáról szóló ismereteket. Ahogyan az egy kiváló könyvhöz és egy kiváló tanárhoz illik.

Gordon Győri János (2009): Tanórakutatás. Oktatás-módszertani Kiskönyvtár IX. Gondolat Kiadó - ELTE PPK Neveléstudományi Intézet, Budapest, 199 oldal

\section{Irodalom}

Stigler, J. W. - Hiebert, J. (1999): The teaching gap: Best ideas from the world's teachers for improving education in the classroom. Free Press, New York. 